\title{
A BRIEF STUDY ON THE STRENGTH PROPERTIES OF MODIFIED CONCRETE USING SILICA FUME AGGREGATES AND PENTA BLENDED CEMENT WITH NANO SILICON DIOXIDE \& POZZOLANIC MATERIALS
}

\author{
S. Ramesh Reddy ${ }^{1}$, G. Raja Sekhar ${ }^{2}$, V. Bhaskar Desai ${ }^{3}$ \\ ${ }^{1}$ Professor, Dept of Civil Engineering, Brindavan Institute of Technology \& Science, Kurnool, A.P and Research \\ Scholar, JNTUA College of Engineering, Anantapuram-515002, A.P. \\ ${ }^{2}$ M.Tech Student, JNTUA College of Engineering, Anantapuram - 515002, A.P. \\ ${ }^{3}$ Professor, Dept. of Civil Engineering,JNTUA College of Engineering, Anantapuram-515002, A.P.
}

\begin{abstract}
Due to rapid civilization there is excessive exploitation of natural resources and artificial light weight aggregate prepared by industrial waste like Silica Fume is a new viable source and usage of Silica fume also contributes to the environmental pollution control Secondly cement is the backbone for global infrastructural development and production of cement emits carbon dioxide and it is said that about 7\% of the world's carbon dioxide emission is attributable to Portland cement. An attempt is made to replace natural aggregate with cold bonded Silica fume aggregate and cement by pozzolanic materials which are also industrial wastes along with Nano $\mathrm{SiO}_{2}$. A mix design was done for M20 grade concrete by IS code method. ACC 53 grade cement was used and natural aggregate was fully replaced with silica fume aggregates along with partial replacement of cement (11\%) with three number of pozzolanic materials like silica fume, slag and fly ash in equal proportions along with varying percentages of nano Nano Silicon dioxide at 0, 0.5, 1 and 1.5 percentage on $11 \%$ of pozzolanic materials. Nano materials possess more pozzolanic action. Because of pozzolanic action, Nano materials react with free lime during hydration and produces more C-S-H gel. After 28 days, various tests were been carried out i.e compressive strength test, flexural strength test, impact test, Mode-II fracture test for concrete with Nano $\mathrm{SiO}_{2}$ and without Nano $\mathrm{SiO}_{2}$. The concrete made with $0.5 \%$ of Nano $\mathrm{SiO}_{2}$ gives optimum results.
\end{abstract}

Keywords: Sintered fly ash aggregates, admixtures, ACC 53 grade, concrete, Nano Silicon dioxide, various tests. ****.

\section{INTRODUCTION}

Production of cement involves significant contribution to environmental pollution and also consumes natural resources like lime stone etc., and there is a need to economise the use of cement. One of the practical solutions to economise cement is to replace cement with supplementary cementitious materials like Silica fume, Slag and Fly ash which are also industrial wastes. Production of artificial aggregate using industrial waste also gives an alternate vent for effective disposal which are otherwise causing air pollution due to their fine ness. An attempt has been made to use silica fume as the basic ingredient in preparing artificial coarse aggregate which is light in nature.

Nano-technology has become one of the influential technologies of this century. The construction sector finds its advantage with Nano-technology; construction industry needs more material and energy resources. Among all the materials used in construction, concrete occupies nearly $70 \%$ of the materials by volume and shows significant impact. The advent of nanotechnology helped in producing more strong and durable material than conventional materials.
The basic purpose of using nano materials in concrete is to improve compressive and flexural strengths at early age; it is possible due to the high surface to volume ratio. The nanomaterial densifies the cement matrix by increasing the $\mathrm{C}-\mathrm{S}-\mathrm{H}$ gel during the pozzolanic reaction of these materials with calcium hydroxide. Also the nano sized particle fills the voids in interfacial transition zone which is present between the cement and aggregate. It also helps to improve the pore structure of concrete. Nano materials also reduce porosity as they absorb less water compared to traditional cementitous materials.

Light weight aggregate preparation is shown in plate 1.

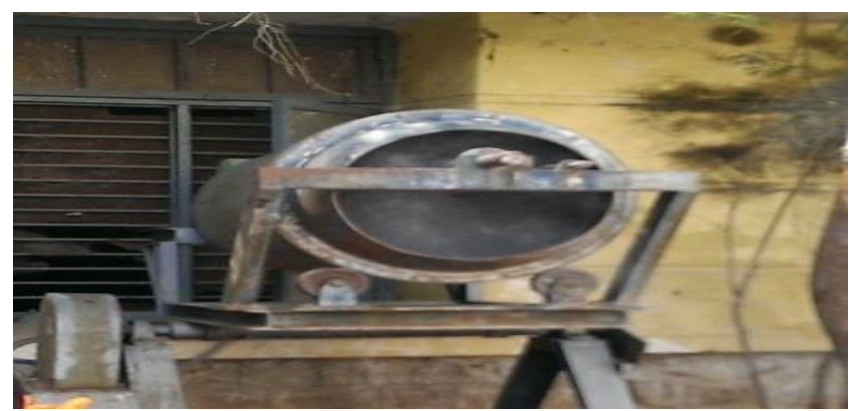

Plate 1.1: Silica fume aggregates 


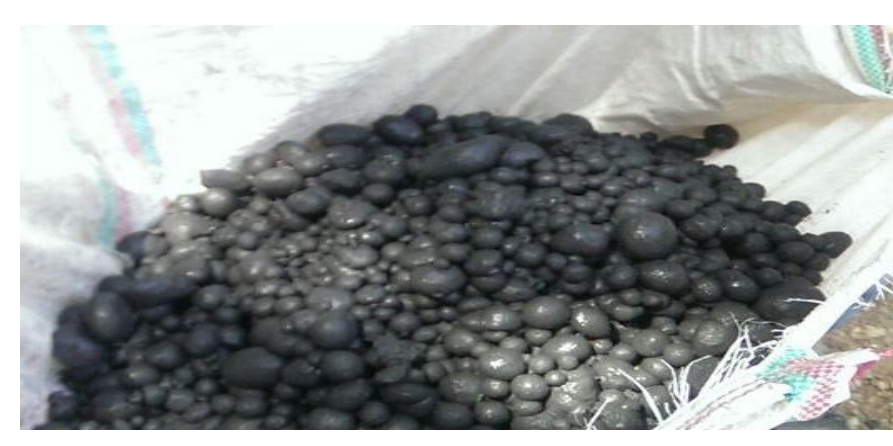

\section{REVIEW OF LITERATURE}

Luciano senff et al., (1) In his research amorphous nano silica particles were incorporated in cement pastes and mortars and their effect on fresh properties was analysed.

Abdul Rahim and Sandanu. R.Nair (2) investigated the influence of nano materials with replacement of cement from 2 to $6 \%$ by Nano $\mathrm{SiO}_{2}, \mathrm{Nano} \mathrm{Al}_{2} \mathrm{O}_{3}$ and $\mathrm{Nano} \mathrm{TiO}_{2}$ along with replacement of cement by $40 \%$ GGBS on $\mathrm{M}_{60}$ grade concrete and found that optimum dosage of Nano $\mathrm{SiO}_{2}$, Nano $\mathrm{Al}_{2} \mathrm{O}_{3}$ is $3 \%$ where as for Nano $\mathrm{TiO}_{2}$ it is at $4 \%$. nanomaterial when mixed along with concrete results in less porous and impermeable concrete. The decrease in mechanical properties after the optimum dosage is due to the excess quantity of nanomaterial present in the concrete than the quantity which is required for combining with liberated lime produced during hydration and therefore the excess silica leaches out leading to the decrease in strength of concrete.

Bhaskar Desai, Satyam et al., (3) Studied the possibility of replacing natural aggregate with artificial cold bonded light weight aggregates produced by using Silica fume in various percentages. It is found that target mean strength of $\mathbf{M}_{20}$ grade of $26.60 \mathrm{~N} / \mathrm{mm}^{2}$ is achieved with $100 \%$ replacement of natural aggregate with Silica fume aggregate after 90 days curing $13.75 \mathrm{~N} / \mathrm{mm}^{2}$ and also found that there is rapid increase in strength of modified concrete when compared to 28 days strength $11.75 \mathrm{~N} / \mathrm{mm}^{2}$.

Prakash Desai, et al., (4) arrived at double central notched specimen geometry which fails in predominant Mode-II failure, they also made finite element analysis to arrive at stress intensity factor. Using this DCN geometry lot of experimental investigation using cement paste, mortar, plain concrete have been studied. Details of this geometry are presented in Plate 2.1.

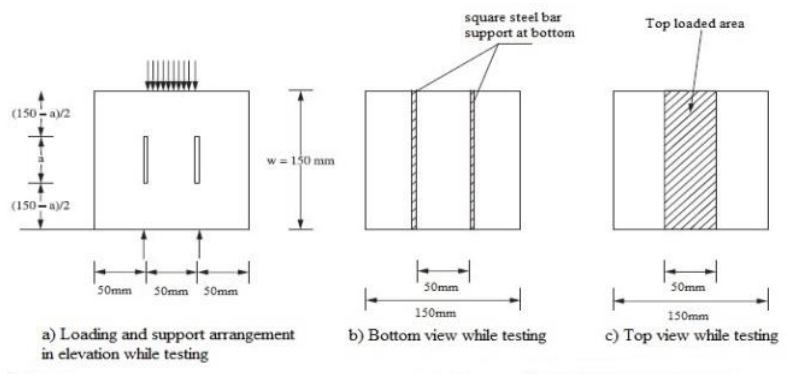

Plate 2.1: Details of DCN specimen geometry
Thorenfeldt, E (5) reported that Light Weight Aggregate Concrete has a faster hardening factor in the initial setting phase than conventional concrete, normally reaching $80 \%$ of the 28 day strength within 7 days. The strength growth from 28 to 90 days is generally low and decreases with increasing concrete strength level. This is assumed to be a consequence of the strength limiting effect of the light weight aggregateas per.

As per Arvind Kumar, Dilip Kumar (6) The possibility exists for the partial replacement of coarse aggregate with Sintered fly ash aggregate produced from Fly Ash generated as waste material from thermal power plants. The sintered fly ash aggregate is produced by mixing materials, Then the mix is made into spherical shape and over dried at a temperature of $1100{ }^{\circ} \mathrm{C}$ in muffle furnace. The maximum compressive strength of $36.25 \mathrm{~N} / \mathrm{mm}^{2}$ is attained at $12 \%$ replacement of Sintered fly ash aggregate and maximum flexural strength of $4.95 \mathrm{~N} / \mathrm{mm}^{2}$ was attained at $8 \%$ replacement At the same water cement ratio, by increasing cement content, the drying shrinkage is increased and sorptivity decreased. Sorptivity $(\mathrm{S})$ is a material property which characterizes the tendency of a porous material to absorb and transmit water by capillarity.

From the brief literature study conducted here it appears that much less attention has been paid earlier on the study of 100 percent replacement of natural coarse aggregate by cold bonded Silica fume aggregate along with penta blended cement with three numbers of pozzolanic materials and Nano $\mathrm{SiO}_{2}$. Hence the present investigation has been under taken.

\section{OBJECTIVE}

- Determining of solution for disposal of industrial wastes hazardous to environment as a useful material in the construction industry.

- To study the mechanical properties of the modified concrete by varying the percentages of $\mathrm{Nano} \mathrm{SiO}_{2}$ in admixture concrete in the order $0.5 \%, 1.0 \%$, and $1.5 \%$.

\section{MATERIALS USED}

The following materials were used for preparing the concrete mix.

ACC cement of 53 grade

1. Fine aggregate i.e sand

2. Coarse aggregate i.e cold bonded silica fume aggregates

3. Fly ash

4. Silica fume

5. Slag

6. Water

\subsection{Cement}

ACC 53 grade cement and locally available sand were used which have fallowing properties. 


\begin{tabular}{|c|c|c|c|}
\hline S.N & Name of the & \multicolumn{2}{|c|}{ Properties of materials } \\
\hline \multirow[t]{5}{*}{1} & \multirow[t]{5}{*}{ Cement } & Specific gravity & 3.26 \\
\hline & & $\begin{array}{l}\text { Initial setting } \\
\text { time }\end{array}$ & 50 minutes \\
\hline & & Final setting time & 460 minutes \\
\hline & & $\begin{array}{l}\text { Normal } \\
\text { consistency }\end{array}$ & $30 \%$ \\
\hline & & $\begin{array}{l}\text { Fineness of } \\
\text { Cement }\end{array}$ & $5 \%$ \\
\hline \multirow[t]{2}{*}{2} & \multirow{2}{*}{$\begin{array}{l}\text { Fine } \\
\text { aggregate }\end{array}$} & Specific gravity & 2.39 \\
\hline & & $\begin{array}{l}\text { Fineness } \\
\text { modulus }\end{array}$ & 3.3 \\
\hline 3 & $\begin{array}{l}\text { Coarse } \\
\text { aggregate } \\
\text { (granite) }\end{array}$ & Specific gravity & 2.6 \\
\hline 4 & $\begin{array}{l}\text { Light weight } \\
\text { aggregate }\end{array}$ & Specific gravity & 1.7 \\
\hline
\end{tabular}

\subsection{Silica Fume Aggregates}

Silica fume is a by product in the form of smoke results from electric furnaces of producing Silicon metal or ferrosilicon alloys. Silicon and ferrosilicon alloys are produced in electric furnaces and the raw materials are quartz, coal and wood chips. Before the mid 1970's nearly all silica fume was discharged into atmosphere. After environmental concerns necessitated collection and land filling became economically justified to use Silica Fume in various applications. Because of chemical and physical properties it is a very reactive pozzolan. Silica fume consists primarily of amorphous (non-crystalline) Nano Silicon dioxide ( $\mathrm{SiO} 2)$. The individual particles are extremely small, approximately 1/100th the size of an average cement particle. Because of its fine particles, large surface area, and the high $\mathrm{SiO}_{2}$ content, silica fume is a very reactive pozzolana. An attempt is made to produce cold bonded Silica fume pellets to use as light weight aggregate.

One of the common techniques while producing the light weight aggregate is by agglomeration technique. In agglomeration technique the pellets are formed by agitation granulation and compaction. The agitation method is not taking any external force rather than the rotational force. With the increasing dosage of water in the binder the cohesive force of the particles increases. Here attempts have been made to form pellets of Silica Fume with various proportions of lime and cement mixing with water. Finally sustainable proportion has been arrived to form pellets and for further studies. Pelletization of Silica Fume was done by using a rotating drum with fixed blades with adjusting inclination. The percentage of binder content was taken by the weight of Silica Fume.

The light weight cold bonded Silica fume aggregates are were tested in the laboratory and the properties are as follows.
Typical physical characteristics of silica fume aggregates

Aggregate Size mm : $12-20$

Specific gravity $\quad: \quad 1.69$

Bulk Density : $\quad$ : $1001 \mathrm{~kg} / \mathrm{m} 3$

Shape : Round pellets

Specific gravity $\quad: \quad 1.70$

\subsection{Casting of Specimens}

The M20 concrete mix is designed using ISI method which gives a mix proportion of 1:1.49:2.88 with water cement ratio of 0.50 . Four different mixes which are adopted are designated as follows.

\begin{tabular}{|l|l|l|l|l|}
\hline $\begin{array}{l}\text { Name } \\
\text { of the } \\
\text { MIX }\end{array}$ & $\begin{array}{l}\text { \% Volume } \\
\text { replacement } \\
\text { of Coarse } \\
\text { aggregate } \\
\text { i.e Silica- } \\
\text { fume } \\
\text { aggregate }\end{array}$ & $\begin{array}{l}\text { Admixtures } \\
\text { in equal } \\
\text { proportions }\end{array}$ & $\begin{array}{l}\text { \% of } \\
\text { Nano } \\
\left.\mathrm{SiO}_{2}\right) \\
\text { on } \\
11 \% \\
\text { of } \\
\text { cement }\end{array}$ & \begin{tabular}{l} 
cement \\
\hline $\mathrm{CNS}_{0}$
\end{tabular} 100 \\
\hline $\mathrm{CNS}_{1}$ & 100 & 0 & 0 & 100 \\
\hline $\mathrm{CNS}_{2}$ & 100 & 11 & 0.5 & 88.945 \\
\hline $\mathrm{CNS}_{3}$ & 100 & 11 & 1.0 & 88.890 \\
\hline
\end{tabular}

To proceed with the experimental program initially steel moulds of size 150x150x150 mm were cleaned brushed with machine oil on all inner faces to facilitate easy removal of specimens afterwards. First fine aggregate and cement along with admixtures silica fume, slag, fly ash and $\mathrm{Nano} \mathrm{SiO}_{2}$ in required percentages were mixed thoroughly and then Silica fume aggregates were added with them. All of these were mixed thoroughly by hand mixing. For each mix fifteen 150X150X150mm cube specimens out of which 12 no of DCN specimens with replacement of cement by $11 \%$ of its weight by pozzolanic materials (Silica fume, fly ash and Slag) and $\mathrm{Nano} \mathrm{SiO}_{2}$ with varying percentages $(0 \%, 0.5 \%$, $1 \%$, and $1.5 \%$ ) on $11 \%$ weight of cement and 3 no's of plain cubes, 3 no's of plain beams were cast. The concrete was poured into the moulds in three layers with each layer being compacted thoroughly with tamping rod 25 times each time to avoid honey combing. Finally all specimens were kept on the table vibrator after filling up the moulds up to the brim. The vibration was effected for 7 seconds and it was maintained constant for all specimens and all other castings. The steel plates forming notches were removed after 3 hours of casting carefully and neatly finished. After 28 days of curing the specimens were taken out of water and were allowed to dry under shade for few hours.

\subsection{Testing of Specimens}

\subsubsection{Compressive Strength of Cubes}

Compressive strength of cubes is calculated by dividing load taken by the specimen by the cross sectional area. Values of compressive strength at different percentages of $\mathrm{Nano}_{\mathrm{SiO}}$ are given in table 1 . 


\subsubsection{Flexural Strength}

Flexural strength is one measure of the tensile strength of the concrete. It is a measure of an unreinforced concrete beam to resist failure in bending. The flexural strength can be determined by standard test method of two point loading or center point loading. In this study, three beams of size $100 * 100 * 500 \mathrm{~mm}$ were tested in two point loading to find the flexural strength. The values are presented in table 2 .

\subsubsection{Modulus of Elasticity}

The theoretical modulus of elasticity has been calculated using IS code formula(8).

$$
\mathrm{E}=5000 * \sqrt{ } \mathrm{f}_{\mathrm{ck}}
$$

Where $\mathrm{f}_{\mathrm{ck}}=$ Characteristic Compressive strength of concrete in $\mathrm{N} / \mathrm{mm}^{2}$

The modulus of elasticity values have been calculated from the another empirical formula suggested by Takafumi(7) (Table:3) is
Where $\mathrm{f}_{\mathrm{ck}}=$ Compressive strength in $\mathrm{N} / \mathrm{mm}^{2}, \gamma=$ Density in $\mathrm{Kg} / \mathrm{m}^{3}, \mathrm{~K}_{1=} 0.95$ (correction factor corresponding to coarse aggregate), $\mathrm{K}_{2}=1.026$, (correction factor corresponding to mineral admixtures)

\subsubsection{Mode II Fracture Test}

For testing DCN specimens of size 150x150x150mm, notches were introduced at one third portion centrally during casting. The compression test on the DCN cubes was conducted on $3000 \mathrm{KN}$ digital compression testing machine. The rate of loading applied was $0.5 \mathrm{KN} / \mathrm{sec}$. Test results shown in table 5 and graphically vide in fig.4.Uniformly distributed load was applied over the central one third part between the notches and square cross section steel supports were provided at bottom along the outer edges of the notches, so that the central portion could get punched/sheared through along the notches on the application of loading.

Table1: Compressive strength of cubes

\begin{tabular}{|c|c|c|c|c|c|c|}
\hline Mix & $\begin{array}{l}\% \text { Volume } \\
\text { replacement } \\
\text { of coarse } \\
\text { aggregate } \\
\text { i.e Silica- } \\
\text { Fume } \\
\text { aggregate }\end{array}$ & $\begin{array}{l}\% \text { of } \\
\text { admixtures } \\
\text { in equal } \\
\text { proportions }\end{array}$ & $\begin{array}{lr}\% & \text { nano } \\
\left(\mathrm{SiO}_{2}\right) & \text { on } \\
11 \% & \text { of } \\
\text { cement } & \end{array}$ & $\begin{array}{ll}\% & \text { of } \\
\text { cement } & \end{array}$ & $\begin{array}{l}\text { compressive } \\
\text { strength in } \\
\mathrm{N} / \mathrm{mm}^{2}\end{array}$ & $\begin{array}{l}\% \text { increase or } \\
\text { decrease of } \\
\text { compressive strength }\end{array}$ \\
\hline $\mathrm{CNS}_{0}$ & 100 & 0 & 0 & 100 & 14.13 & 0 \\
\hline $\mathrm{CNS}_{1}$ & 100 & 11 & 0.5 & 88.945 & 25.56 & 80.89 \\
\hline $\mathrm{CNS}_{2}$ & 100 & 11 & 1 & 88.890 & 22.44 & 58.81 \\
\hline $\mathrm{CNS}_{3}$ & 100 & 11 & 1.5 & 88.835 & 19.52 & 38.14 \\
\hline
\end{tabular}

Table 2: Flexural strength of beams

\begin{tabular}{|c|c|c|c|c|c|c|}
\hline Mix & $\begin{array}{l}\text { \% Volume } \\
\text { replacement of } \\
\text { coarse aggregate } \\
\text { i.e Silica-Fume } \\
\text { aggregate }\end{array}$ & $\begin{array}{l}\% \text { of } \\
\text { admixtures } \\
\text { in equal } \\
\text { proportions }\end{array}$ & $\begin{array}{lr}\% & \text { nano } \\
\left(\mathrm{SiO}_{2}\right) & \text { on } \\
11 \% & \text { of } \\
\text { cement } & \end{array}$ & $\%$ of cement & $\begin{array}{l}\text { Flexural } \\
\text { strength in } \\
\mathrm{N} / \mathrm{mm}^{2}\end{array}$ & $\begin{array}{l}\% \text { increase or decrease } \\
\text { of flexural strength }\end{array}$ \\
\hline $\mathrm{CNS}_{0}$ & 100 & 0 & 0 & 100 & 2.11 & 0 \\
\hline $\mathrm{CNS}_{1}$ & 100 & 11 & 0.5 & 88.945 & 2.80 & 32.7 \\
\hline $\mathrm{CNS}_{2}$ & 100 & 11 & 1 & 88.890 & 2.10 & -0.33 \\
\hline $\mathrm{CNS}_{3}$ & 100 & 11 & 1.5 & 88.835 & 1.96 & -6.96 \\
\hline
\end{tabular}

Table 3: Modulus of elasticity

\begin{tabular}{|c|c|c|c|c|c|c|c|}
\hline Mix & $\begin{array}{l}\% \text { Volume } \\
\text { replacement } \\
\text { of coarse } \\
\text { aggregate } \\
\text { i.e Silica- } \\
\text { Fume } \\
\text { aggregate }\end{array}$ & $\begin{array}{l}\% \text { of } \\
\text { admixtures } \\
\text { in equal } \\
\text { proportions }\end{array}$ & $\begin{array}{l}\% \text { nano } \\
\left(\mathrm{SiO}_{2}\right) \text { on } \\
11 \% \text { of } \\
\text { cement }\end{array}$ & $\begin{array}{l}\% \text { of } \\
\text { cement }\end{array}$ & $\begin{array}{l}\text { Modulus of } \\
\text { elasticity in } \\
\mathrm{N} / \mathrm{mm}^{2} \text { as I.S } \\
456: 2000 \\
\mathrm{E}=5000 * \sqrt{\mathrm{fck}}\end{array}$ & $\begin{array}{l}\text { Modulus } \\
\text { elasticity of } \\
\text { on empirical } \\
\text { formula } \\
\mathrm{E}=\mathrm{k}_{1} \mathrm{k}_{2} * 1.486 * 10^{-} \\
3 * \mathrm{f}_{\mathrm{ck}} 1 / 3 * \gamma^{2} \\
\mathrm{~K}_{1=} \quad 0.95, \quad \mathrm{~K}_{2}= \\
1.026\end{array}$ & $\begin{array}{ll}\% \text { increase } & \text { or } \\
\text { decrease } & \text { of } \\
\text { modulus } & \text { of } \\
\text { elasticity } & \\
\text { based on } & \text { I.S } \\
\text { code } & \end{array}$ \\
\hline $\mathrm{CNS}_{0}$ & 100 & 0 & 0 & 100 & $1.84 \times 10^{4}$ & 1.82 & 0.00 \\
\hline
\end{tabular}




\begin{tabular}{|l|l|l|l|l|l|l|l|}
\hline $\mathrm{CNS}_{1}$ & 100 & 11 & 0.5 & 88.945 & $2.54 \times 10^{4}$ & 1.87 & 47.91 \\
\hline $\mathrm{CNS}_{2}$ & 100 & 11 & 1 & 88.890 & $2.31 \times 10^{4}$ & 1.75 & 26.00 \\
\hline $\mathrm{CNS}_{3}$ & 100 & 11 & 1.5 & 88.835 & $2.20 \times 10^{4}$ & 1.79 & 18.92 \\
\hline
\end{tabular}

Table 4: Density

\begin{tabular}{|l|l|l|l|l|l|l|}
\hline Mix & $\begin{array}{l}\% \\
\text { replacement of coarse } \\
\text { aggregate i.e Silica- } \\
\text { Fume aggregate }\end{array}$ & $\begin{array}{l}\% \text { of } \\
\text { admixtures } \\
\text { in equal } \\
\text { proportions }\end{array}$ & $\begin{array}{l}\% \text { nano } \\
\left(\mathrm{SiO}_{2}\right) \text { on } \\
11 \% \text { of } \\
\text { cement }\end{array}$ & $\begin{array}{l}\% \text { of } \\
\text { cement }\end{array}$ & $\begin{array}{l}\text { Density in } \\
\mathrm{Kg} / \text { cum }\end{array}$ & $\begin{array}{l}\text { Percentage increase } \\
\text { or decrease in in } \\
\text { density }\end{array}$ \\
\hline $\mathrm{CNS}_{0}$ & 100 & 0 & 0 & 100 & 2044 & 0 \\
\hline $\mathrm{CNS}_{1}$ & 100 & 11 & 0.5 & 88.945 & 2025 & -0.929 \\
\hline $\mathrm{CNS}_{2}$ & 100 & 11 & 1 & 88.890 & 2027 & -0.832 \\
\hline $\mathrm{CNS}_{3}$ & 100 & 11 & 1.5 & 88.835 & 2048 & 0.196 \\
\hline
\end{tabular}

Table 5: Ultimate loads in Mode-II fracture test

\begin{tabular}{|c|c|c|c|c|c|c|c|c|c|c|c|}
\hline \multirow{2}{*}{$\begin{array}{l}\text { Name of } \\
\text { the mix }\end{array}$} & \multirow[b]{2}{*}{$\begin{array}{l}\% \\
\text { Volume } \\
\text { replace } \\
\text { ment of } \\
\text { coarse } \\
\text { aggregat } \\
\text { e i.e } \\
\text { Silica- } \\
\text { Fume } \\
\text { aggregat } \\
\text { e }\end{array}$} & \multirow[b]{2}{*}{$\begin{array}{l}\% \text { of } \\
\text { admixt } \\
\text { ures in } \\
\text { equal } \\
\text { propor } \\
\text { tions }\end{array}$} & \multirow[b]{2}{*}{$\begin{array}{l}\% \\
\text { nano } \\
\left(\mathrm{SiO}_{2}\right. \\
) \quad \text { on } \\
11 \% \\
\text { of } \\
\text { ceme } \\
\mathrm{nt}\end{array}$} & \multicolumn{2}{|l|}{$\mathrm{a} / \mathrm{w}=0.3$} & \multicolumn{2}{|l|}{$\mathrm{a} / \mathrm{w}=0.4$} & \multicolumn{2}{|l|}{$\mathrm{a} / \mathrm{w}=0.5$} & \multicolumn{2}{|l|}{$\mathrm{a} / \mathrm{w}=0.6$} \\
\hline & & & & $\begin{array}{l}\text { Ultima } \\
\text { te load } \\
\text { in KN }\end{array}$ & $\begin{array}{l}\% \\
\text { increas } \\
\text { e or } \\
\text { decreas } \\
\text { e of } \\
\text { ultimat } \\
\text { e load }\end{array}$ & $\begin{array}{l}\text { Ultima } \\
\text { te load } \\
\text { in KN }\end{array}$ & $\begin{array}{l}\% \\
\text { increas } \\
\text { e or } \\
\text { decreas } \\
\text { e of } \\
\text { ultimat } \\
\text { e load }\end{array}$ & $\begin{array}{l}\text { Ultima } \\
\text { te load } \\
\text { in KN }\end{array}$ & $\begin{array}{l}\% \\
\text { increas } \\
\text { e or } \\
\text { decreas } \\
\text { e of } \\
\text { ultimat } \\
\text { e load }\end{array}$ & $\begin{array}{l}\text { Ultima } \\
\text { te load } \\
\text { in KN }\end{array}$ & $\begin{array}{l}\% \\
\text { increas } \\
\text { e or } \\
\text { decreas } \\
\text { e of } \\
\text { ultimat } \\
\text { e load }\end{array}$ \\
\hline $\mathrm{SiO}_{2}-0$ & 100 & 0 & 0 & 86.33 & 0 & 83 & 0 & 60.67 & 0 & 57.33 & 0 \\
\hline $\mathrm{SiO}_{2}-0.5$ & 100 & 11 & 0.5 & 89.67 & 3.86 & 87.67 & 5.62 & 64.33 & 6.03 & 61.33 & 6.97 \\
\hline $\mathrm{SiO}_{2}-1$ & 100 & 11 & 1 & 80.00 & $\begin{array}{l}-7.33 \\
\end{array}$ & 82.667 & -0.4 & 60.67 & 0 & 56.2 & -1.97 \\
\hline $\mathrm{SiO}_{2}-1.5$ & 100 & 11 & 1.5 & 78.51 & -9.05 & 79 & -4.81 & 57.33 & -5.50 & 54.7 & -4.58 \\
\hline
\end{tabular}

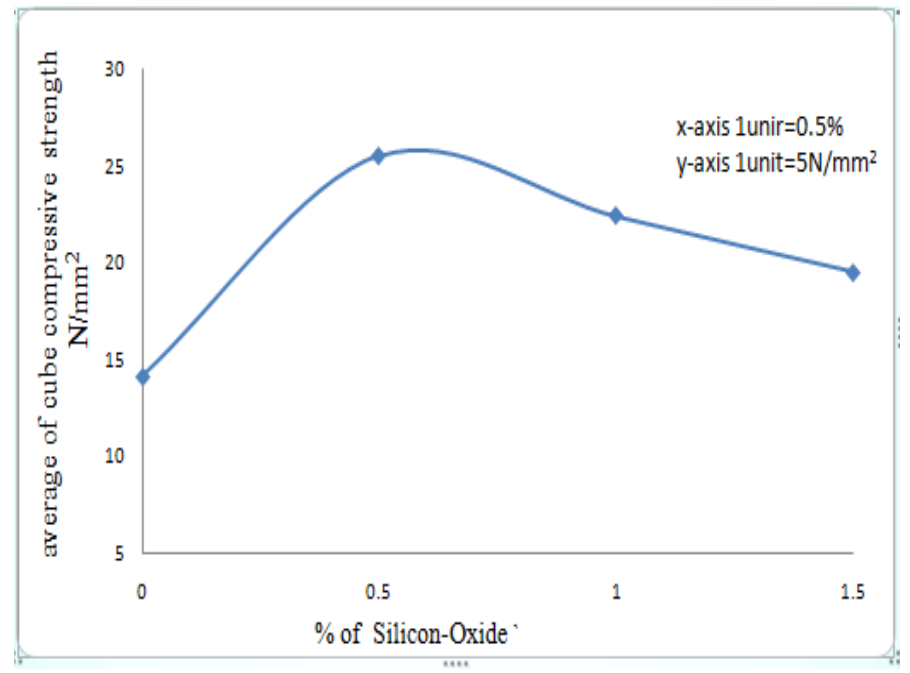

Fig 1: Compressive strength of cubes

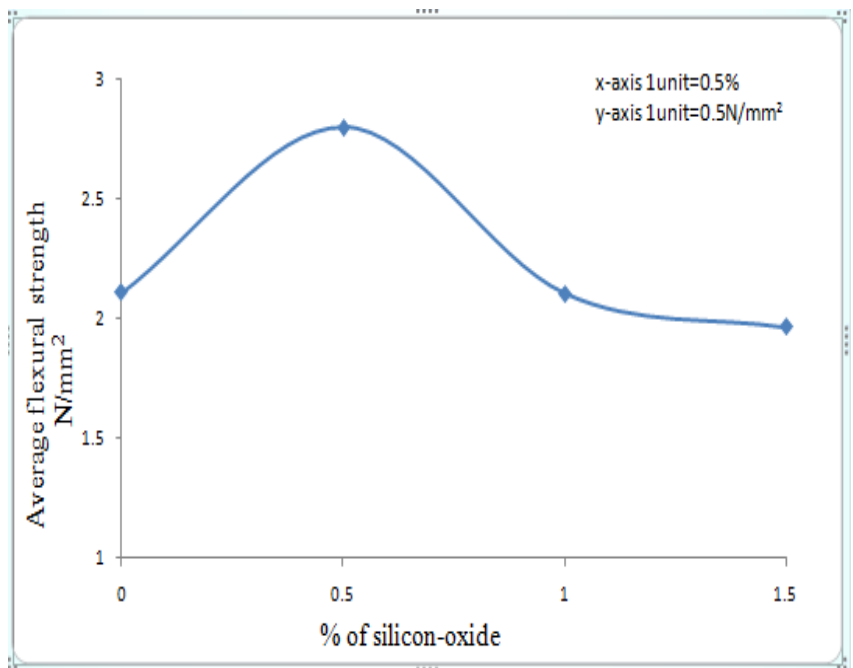

Fig 2: flexural strength 


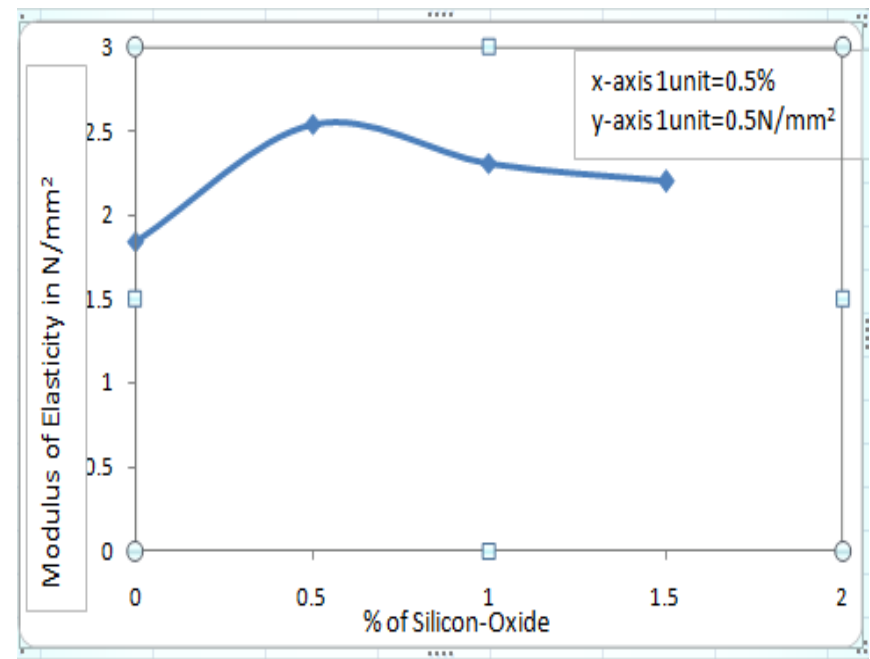

Fig 3: Modulus of elasticity

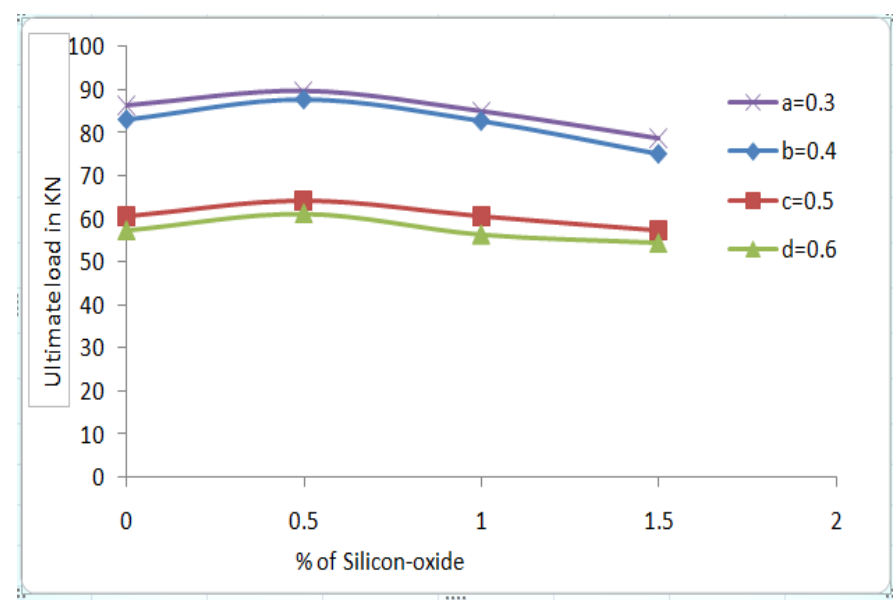

Fig 4: superimposed loads for in Mode-II different a/w ratios

\section{DISCUSSION OF TEST RESULTS}

\subsection{Influence of Nano $\mathrm{SiO}_{2}$ on Cube Compressive}

\section{Strength}

In the present study natural aggregate has been fully replaced with silica fume aggregates. The variations of compressive strength verses percentage replacement of cement with Nano Silicon dioxide addition at 28 days are shown vide figure no:1. From the above figures it may be observed that with the addition of $0.5 \%$ Nano Silicon dioxide there is considarable improvement of cube compressive strength and with further addition of Nano Silicon oxide there is decrease in strength. The results are tabulated in table 1 .

\subsection{Influence of Nano $\mathrm{SiO}_{2}$ on Flexural Strength of}

\section{Beam Specimens}

In the present study natural aggregate is fully replaced with silica fume aggregates. The variation of flexural strength for various percentages of nano $\mathrm{SiO}_{2}$ is presented in fig-2 and the results are tabulated in table 2. From the above figure it may be observed that with the addition of $0.5 \%$ Nano
Silicon dioxide there is an improvement of flexural strength and with further addition of Nano Silicon oxide there is a decrease in strength and is almost following the trend of Cube compressive strength.

\subsection{Influence of $\mathrm{Nano}^{\mathrm{SiO}}{ }_{2}$ on Modulus of Elasticity}

The modulus of elasticity results with various percentages of $\mathrm{SiO}_{2}$ are presented in table 3 for 28 days based on IS code methods and the empirical formula as mentioned above. From the results it is observed that modulus of elasticity has been increased with addition of $0.5 \% \mathrm{Nano}^{\mathrm{SiO}_{2}}$ and with further addition of Nano $\mathrm{SiO}_{2}$ and afterwards it is decreased and the trend is that of flexural strength. It is also observed that the modulus of elasticity values calculated from IS codes are higher compared to empirical formula.

\subsection{Discussion on the Effect of $\mathrm{Nano}^{\mathrm{SiO}_{2}}$ on in}

\section{Plane Shear Strength}

All the DCN specimens with different a/w ratios i.e 0.3, 0.4, 0.5 and 0.6 and with different percentages of $\mathrm{SiO}_{2}$ were tested with load in Mode-II (in plane shear). The variations of ultimate loads and percentage increase or decrease in ultimate loads verses percentage replacement of cement with Nano $\mathrm{SiO}_{2}$ for different a/w ratios after 28 days are presented in table 5 and graphical variations are presented in fig 4 . The ultimate loads in Mode- II shear decreased with increase in $\mathrm{a} / \mathrm{w}$ ratios. From the results it is observed that ultimate loads in Mode-II has been increased with addition of $0.5 \% \mathrm{Nano}_{\mathrm{SiO}_{2}}$ and with further addition of $\mathrm{Nano}_{\mathrm{SiO}}$ it is decreased and the trend is that of flexural strength.

\subsection{Influence of Nano $\mathrm{SiO}_{2}$ on Density}

Density of modified concrete with cold bonded Silica fume aggregates with $\mathrm{Nano} \mathrm{SiO}_{2}$ are decreased and the decrease in density is around $15 \%$ when compared with that for natural aggregate concrete.

\subsection{Discussion of Crack Patterns in Cubes, Cylinders, Beams and DCN Specimens}

In case of cubes, the initial cracks are developed at top and propagated to the bottom with the increase in load and they are widened along the edges of cubes. In case of cylinders, the initial cracks are developed at top or bottom side with the increase in load the cracks are widened at central height. In the flexural beams all 9 beams have failed in flexural mode. As the load increases the flexural cracks initiates in the pure bending zone and the first cracks appears almost in the mid span. As the load increases, existing cracks propagated are observed and new cracks have developed along the span. Final failure occurs in the middle portion. The failure of the DCN specimen is such that the crack patterns obtained for DCN specimen geometry are mostly along the notch depths. During testing, for most of the specimen initial hair line cracks started at the top of one or both the notches, and as the load was increased further, the cracks widened and propagated at an inclination and 
sometimes to the middle of the top loaded zone. In a few cases, initial cracks started at the bottom of the one or both notches. As the load was increased propagation of these cracks at an inclination was observed along with the formation of cracks at top of the notches. These cracks finally propagated toward the middle of the top loaded zone leading to failure of the specimen. In some cases cracks formed either side at two edges of the supporting load bearing plate at the bottom or at the loaded length at top side. For most of the specimens with $\mathrm{a} / \mathrm{w}=0.3,0.4,0.5,0.6$, as the load was applied formation of initial hair line cracks at the top of one or both the notches was observed. With the increase of load propagation of these cracks in more or less vertical direction along with the formation of new cracks at the bottom of one or both the notches was observed.

\section{CONCLUSION}

- The target mean strength of $\mathbf{M}_{20}$ conventional concrete is $26.60 \mathrm{~N} / \mathrm{mm}^{2}$. From the experimental study it is observed that the 28 days cube compressive strength of modified concrete with $100 \%$ Silica fume aggregate is $14.13 \mathrm{~N} / \mathrm{mm}^{2}$ and with replacement of cement by $11 \%$ with three numbers of pozzolanic materials i.e., Silica fume, Slag and Fly ash in equal proportions and $0.5 \%$ of $\mathrm{Nano} \mathrm{SiO}_{2}$ the cube compressive strength of modified concrete rises to $25.56 \mathrm{~N} / \mathrm{mm}^{2}$ with percent increase of 80.89 .

- With addition of $0.5 \%$ percentage of $\mathrm{Nano}^{\mathrm{Si}_{\mathrm{O} 2}}$ and with constant $11 \%$ pozzolanic materials replacing the cement there is an increase in flexural strength and Young's modulus and with further increase of Nano $\mathrm{Si}_{\mathrm{O} 2}$ content beyond $0.5 \%$ there is a decrease in both the values.

- From the analysis of test results it is concluded that young's modulus calculated from IS code is higher compared to empirical formula.

- It is observed that with the increase in the $\mathrm{a} / \mathrm{w}$ ratio there is decrease in ultimate load under Mode-II shear and there is increase in ultimate loads with addition of $0.5 \%$ percentage of $\mathrm{Nano}^{\mathrm{SiO}_{2}}$ and with constant $11 \%$ pozzolanic materials replacing the cement and with further increase of $\mathrm{Nano}^{\mathrm{SiO}} \mathrm{S}_{2}$ content there is decrease in both values

- The light weight concrete prepared by $100 \%$ silica fume aggregate as coarse aggregate is no way inferior to the natural aggregate and also consumption of cement can be reduced by about $11 \%$.

\section{REFERENCES}

[1] Luciano Senff et al., Effect of nano-silica on rheology and fresh properties of cement pastes and mortars Construction and Building Materials 23 (2009) 24872491

[2] Abdul Rahim and Sandanu. R.Nair , " influence of NAno materials in high Strength concrete", Journal of chemical and pharmaceutical sciences special issue 3 : August 2016,P.P 15-22

[3] Bhaskar Desai, Satyam et al., "Some studies on Mode-II fracture of artificial light weight silica fume pettized aggregate concrete" International journal of civil Engineering and Technology, volume 5, issue 2, February (2014), PP. 33-51

[4] Prakash desai, B.K.Raghu Prasad and V.Bhaskar Desai, "Mode - II fracture of cementitious materialspart - I : Studies on specimens of some new geometries", Journal of Structural Engineering, Vol.26, No.1, April 1999, pp.11-18.

[5] Thorenfeldt, E., Design Criteria of Light weight Aggregate Concrete. CEB/FIP International Symposium on Structural Light weight Aggregate Concrete, Sandefjord, Norway, pp. 720- 732, 1995.

[6] Arvind Kumar, Dilip Kumar "Use of Sintered Fly Ash Aggregates as Coarse Aggregate in concrete,SSRG International Journal of Civil Engineering (SSRG-IJCE)- volume1issue4 September 2014

[7] Takafumi Noguchi, et.al (2009) “ A Practical Equation for Elastic Modulus of Concrete". ACI structural journal/Sept-Oct 2009, technical paper title no. $126-$ S64.

[8] I.S.Code 456-2000 "Code of practice for plain and reinforced concrete" Bureau of Indian Standards, New Delhi. 